\title{
Antimicrobial Glycosides and Derivatives from Roots of Picralima nitida
}

\author{
Jacques Kouam (Corresponding author) \\ Department of Organic Chemistry, Faculty of Sciences, University of Yaounde I \\ P.O. Box 812, Yaounde, Cameroon \\ E-mail: kouamjac@yahoo.fr \\ Laure B. K. Mabeku \& Jules R. Kuiate \\ Department of Biochemistry, Faculty of Sciences, University of Dschang \\ P.O.Box 67, Dschang, Cameroon \\ Alembert T. Tiabou \\ Institute of Medical Research and Medicinal Plants Studies (IMPM) \\ P.O. Box 6163, Yaounde, Cameroon \\ Zacharias T. Fomum (Note 1) \\ Department of Organic Chemistry, Faculty of Sciences, University of Yaounde I \\ P.O. Box 812, Yaounde, Cameroon
}

Received: December 28, 2010 Accepted: January 13, 2011 doi:10.5539/ijc.v3n2p23

\begin{abstract}
Phytochemical screening was performed on the roots of Picralima nitida, resulting in the isolation of three new coumestan glycosides, 3-hydroxy-9-methoxy-2-[2'(E)-3'-methyl-4'-O- $\beta$-D-galactopyranosylbutenyl]-8isoprenylcoumestan (1), 3-hydroxy-9-methoxy-2-[2'(E)-3'-methyl-4'-O- $\beta$-D-glucopyranosylbutenyl]-8-[2" $(E)$ -3"-methyl-4"-oxobutenyl]coumestan (2), and 3-hydroxy-9-methoxy-4-[2' $(E)-3$ '-methyl-4'-O- $\beta$-Dglucopyranosylbutenyl]-8-[2"(E)-3"-methyl-4"-oxobutenyl]coumestan (3). Acid hydrolysis of 1, 2 and 3 afforded three new coumestan, 3-hydroxy-9-methoxy-2-[2' $(E)-4$ '-hydroxy-3'-methylbutenyl]-8isoprenylcoumestan (4), 3- hydroxy-9-methoxy-2-[2'(E)-4'-hydroxy-3'-methylbutenyl]-8-[2"'(E)-3"-methyl-4"oxobutenyl]coumestan (5), and 3-hydroxy-9-methoxy-4-[2'(E)-4'-hydroxy-3'-methylbutenyl]-8-[2" $(E)-3$ "methyl-4"-oxobutenyl]coumestan (6), respectively. Structures of these compounds were elucidated on the basis of spectroscopic data and chemical transformations. Compounds 1 - $\mathbf{6}$ showed antimicrobial activities against Escherichia coli, Staphylococcus aureus, and Proteus vulgaris.
\end{abstract}

Keywords: Picralima nitida, Coumestan, Galactopyranoside, Glucopyranoside, Antimicrobial

\section{Introduction}

Picralima nitida Stapf (Apocynaceae) is an entirely glabrous shrub of 3-10 m high. Its fruits are ovoid and yellowish at maturity (Adjanohoun et al. 1996). This plant is widely distributed throughout Africa forest regions. Throughout its distribution area the seeds, bark and roots of $P$. nitida have a reputation as a febrifuge and remedy for malaria ( Kouitcheu et al. 2008). They are also extensively used for pain relief and to treat chest and stomach problems, pneumonia and intestinal worms. Usually, the seeds or bark are crushed or chewed and eaten for this purpose, or a decoction from the roots, seeds or bark is drunk (Adjanohoun et al. 1996; Ezeamuzieet al. 1994). As part of our continuing study on searching for the bioactive flavonoids constituents from West Africa medicinal plants (Kazie et al. 2009), phytochemical screening was performed on the roots of P. nitida, resulting in the isolation of three new coumestan glycosides 1, 2 and $\mathbf{3}$. Acid hydrolysis of these products yielded three new coumestan derivatives $\mathbf{4}, \mathbf{5}$ and $\mathbf{6}$, respectively. These six compounds showed antimicrobial activities against 
E. coli, S. aureus, and P. vulgaris. We herein describe the isolation, structural elucidation and biological activities of these compounds.

\section{Experimental}

\subsection{General Procedures}

Melting points were determined on X-4 digital micro-melting point apparatus and were uncorrected. Optical rotations were measured with a Perkin-Elmer 341 digital polarimeter. The NMR spectra were recorded with a Bruker AMX-500 (500 MHz for ${ }^{1} \mathrm{H}-\mathrm{NMR}$ and $125 \mathrm{MHz}$ for $\left.{ }^{13} \mathrm{C}-\mathrm{NMR}\right)$. Samples were run in DMSO- $d_{6}$ or $\mathrm{CDCl}_{3}$. Chemical shifts were given in (ppm) with tetramethylsilane as an internal standard $(0.00 \mathrm{ppm})$. The HRFABMS spectrum was obtained with a Kratos MS 25 instrument with a DS-55 data system, and collision gas $\mathrm{Xe}$ (ion gun conditions $6 \mathrm{KV}$ and $10 \mathrm{~mA}$ ). The EI mass spectra (at $70 \mathrm{eV}$ ) were recorded on a JEOLMSRoute mass spectrometer. IR spectra were run from $\mathrm{KBr}$ pellets on a Perkin-Elmer 577 spectrometer. HPLC was performed by using a system comprised of a CCPM pump, a CCP PX-8010 controller, an RI-8010 detector and a Shodex OR-2 detector, and a Rheodyne injection port with a $20 \mu \mathrm{l}$ sample loop. Sephadex LH-20, Si gel GF 254 (Merck) and Si gel 60 (70-2 mesh ASTM) (Merck) were used for CC. Silica gel 60 (0.25 mm, Merck) was used for TLC.

\subsection{Plant Material}

Roots of P. nitida were collected in Zo-Etélé, south region of Cameroon in January 2002. The plant was identified at the National Herbarium, Yaounde, where a voucher specimen is deposited (No.2136/SRFK)

\subsection{Extraction and Isolation of Compounds}

Dried ground roots of $P$. nitida $(13 \mathrm{Kg})$ was immersed in $\mathrm{MeOH}(35 \mathrm{~L})$ and kept for $72 \mathrm{~h}$ at $25{ }^{\circ} \mathrm{C}$. After filtration the solvent was removed by rotary evaporator under reduce pressure. The extract obtained (302 $\mathrm{g})$ was partitioned with $2 \% \mathrm{H}_{2} \mathrm{SO}_{4} / \mathrm{EtOAc}$. The EtOAc phase $(102 \mathrm{~g})$ was chromatographed over silica gel $(400 \mathrm{~g})$. Elution with Hexane, Hexane- EtOAc (75/25), (50/50), (25/75), EtOAc, EtOAc-MeOH (25/75) and MeOH gave seven fractions I (7.6 g), II (5.5 g), III (11.2 g), IV (10.8 g), V(17.5 g), VI(15.4 g) and VII(29.7 g), respectively. Fraction V was again chromatographed on Sephadex LH20 (100 g) using methanol as eluent. Ninety-five fractions, each of $300 \mathrm{~mL}$, were collected and combined on the basis of TLC evidence. Fractions 8-21 (3 g) was purified, using preparative TLC and $\mathrm{MeOH} / \mathrm{CHCl}_{2} / \mathrm{H} 2 \mathrm{O}(5 / 4.75 / 0.25)$ as the development solvent, to give compound $\mathbf{1}(56.2 \mathrm{mg}), \mathbf{2}(48.5 \mathrm{mg})$ and $\mathbf{3}(52.8 \mathrm{mg})$.

\subsection{Physical and Spectroscopic Data of Compounds 1-3}

\section{Compound 1}

M.p. $259-260{ }^{\circ}$ C.-Rf. $33 \%$.- UV/ $(\mathrm{MeOH}) \lambda_{\max }\left(\log \varepsilon_{\max }\right): 244 \mathrm{~nm}(4.40), 315 \mathrm{~nm}(4.05), 355 \mathrm{~nm}(4.46)$.- $[\alpha]^{22} \mathrm{D}$ $=-44^{\circ}(c=0.11, \mathrm{MeOH})$.- IR $(\mathrm{KBr}) v_{\max }=3405-3200,1724,1715,1625,1600,1504,1222,1035,810 \mathrm{~cm}^{-1}$. ${ }^{1} \mathrm{H}-\mathrm{NMR}\left(\right.$ Measured in DMSO- $d_{6}$ ) (See Table 2). ${ }^{13} \mathrm{C}-\mathrm{NMR}\left(\right.$ Measured in DMSO- $d_{6}$ ) (see Table 1). - HRMS $(\mathrm{FAB}, 6 \mathrm{kV}): m / z=596.2120[\mathrm{M}]^{+}\left(\right.$calcd. for $\left.\mathrm{C}_{32} \mathrm{H}_{36} \mathrm{O}_{11}: 596.2121\right)$.

\section{Compound 2}

M.p. $264-265{ }^{\circ}$ C.-Rf. $31 \%$. $-\mathrm{UV} /(\mathrm{MeOH}) \lambda_{\max }\left(\log \varepsilon_{\max }\right): 245 \mathrm{~nm}(4.42), 314 \mathrm{~nm}(4.06), 355 \mathrm{~nm}(4.44) .-[\alpha]^{22}$ $=-53^{\circ}(c=0.11, \mathrm{MeOH}) .-\mathrm{IR}(\mathrm{KBr}) v_{\max }=3405-3200,1725,1715,1625,1605,1505,1220,1034,810 \mathrm{~cm}^{-1} .-$ ${ }^{1} \mathrm{H}-\mathrm{NMR}\left(\right.$ Measured in DMSO- $d_{6}$ ) (See Table 2) $.{ }^{13} \mathrm{C}-\mathrm{NMR}\left(\right.$ Measured in DMSO- $d_{6}$ ) (see Table 1). - HRMS $(\mathrm{FAB}, 6 \mathrm{kV}): m / z=610.1912[\mathrm{M}]^{+}\left(\right.$calcd. for $\left.\mathrm{C}_{32} \mathrm{H}_{34} \mathrm{O}_{12}: 610.1914\right)$.

\section{Compound 3}

M.p. $261-262^{\circ}$ C.-Rf. $32 \%$. - UV/(MeOH) $\lambda_{\text {max }}\left(\log \varepsilon_{\max }\right): 245 \mathrm{~nm}(4.41), 315 \mathrm{~nm}(4.07), 354 \mathrm{~nm}(4.42)$. - $[\alpha]^{22}$ $=-36^{\circ}(c=0.11, \mathrm{MeOH}) .-\mathrm{IR}(\mathrm{KBr}) v_{\max }=3405-3200,1724,1712,1625,1605,1504,1220,1035,810 \mathrm{~cm}^{-1} .-$ ${ }^{1}$ H-NMR (Measured in DMSO- $d_{6}$ ) (See Table 2) . - ${ }^{13}$ C-NMR (Measured in DMSO- $d_{6}$ ) (see Table 1). - HRMS (FAB, $6 \mathrm{kV}$ ): $\mathrm{m} / z=610.1911[\mathrm{M}]^{+}$Calcd for $\mathrm{C}_{32} \mathrm{H}_{34} \mathrm{O}_{12}: \mathrm{m} / \mathrm{z}=610.1914$

\subsection{Acid Hydrolysis and Identification of Sugar}

Compounds 1, 2 and $3\left(16.5 \mathrm{mg}\right.$ each) were separately refluxed with $15 \% \mathrm{HCl} / \mathrm{MeOH}(12 \mathrm{ml})$ at $80^{\circ} \mathrm{C}$ for $4 \mathrm{~h}$. After cooling, each reaction mixture was concentrated and the residue partitioned with $\mathrm{CHCl}_{3} / \mathrm{H}_{2} \mathrm{O}$. The organic layer was concentrated to dryness to yield $9.8 \mathrm{mg}$ of white material (M1) from 1, 10.1 $\mathrm{mg}$ of white material(M2) from 2 and $9.9 \mathrm{mg}$ of white material(M3) from 3. After purification by preparative-TLC, using silica gel and $\mathrm{MeOH} / \mathrm{CH}_{2} \mathrm{Cl}_{2}$ (0.25:9.75) as development solvent, M1, M2 and M3 yielded compounds 4 (8.1 mg), 5 (7.2 mg) and $6(7.8 \mathrm{mg})$, respectively. Each aqueous layer was evaporated and the residue was analysed by HPLC under 
the following conditions: column, Aminex HPX-87H (7.8 mm i.d. x $300 \mathrm{~mm}$ ); solvent, $5 \mathrm{mM} \mathrm{H}_{2} \mathrm{SO}_{4}$; flow rate, $0.6 \mathrm{ml} / \mathrm{min}$; detection, refractive index and optical rotation. The sugars were confirmed as D-galactose, and D-glucose by comparison of their retention times and optical rotations with those of authentic samples: retention times (min), 9.62 (D-galactose, positive optical rotation), 8.99 (D-glucose, positive optical rotation).

\subsection{Physical and Spectroscopic Data of Compounds 4-6}

\section{Compound 4}

White powder.-M.p. $208-209^{\circ}$ C.-Rf. $52 \%$. - UV/(MeOH) $\lambda_{\max }\left(\log \boldsymbol{\varepsilon}_{\max }\right): 243 \mathrm{~nm}(4.40), 315 \mathrm{~nm}(4.09), 354 \mathrm{~nm}$ (4.45).- IR (KBr) $v_{\max }=3400-3200,1725,1715,1624,1500,1222,1034,810 \mathrm{~cm}^{-1}$. - ${ }^{1} \mathrm{H}-\mathrm{NMR}($ Measured in $\mathrm{CDCl}_{3}$ )(See Table 2) . - ${ }^{13} \mathrm{C}-\mathrm{NMR}\left(\right.$ Measured in $\left.\mathrm{CDCl}_{3}\right)\left(\right.$ see Table 1). - HRMS: $m / z=434.1591[\mathrm{M}]^{+}$(calcd. for $\left.\mathrm{C}_{26} \mathrm{H}_{26} \mathrm{O}_{6}: 434.1590\right)$.

\section{Compound 5}

White powder.-M.p. $204-205^{\circ}$ C.-Rf. $51 \%$. - UV/(MeOH) $\lambda_{\max }\left(\log \varepsilon_{\max }\right): 244 \mathrm{~nm}(4.40), 315 \mathrm{~nm}(4.09), 354 \mathrm{~nm}$ (4.45).- IR (KBr) $v_{\max }=3405-3250,1725,1712,1625,1450,1220,1035,810 \mathrm{~cm}^{-1}$. - ${ }^{1} \mathrm{H}-\mathrm{NMR}$ (Measured in $\left.\mathrm{CDCl}_{3}\right)\left(\right.$ See Table 2) . - ${ }^{13} \mathrm{C}-\mathrm{NMR}$ (Measured in $\left.\mathrm{CDCl}_{3}\right)\left(\right.$ see Table 1). - HRMS: $m / z=448.1381[\mathrm{M}]^{+}$(calcd. for $\mathrm{C}_{26} \mathrm{H}_{24} \mathrm{O}_{7}: 448.1382$ ).

\section{Compound 6}

White powder.-M.p. $208-209^{\circ}$ C.-Rf. $53 \%$.- UV/(MeOH) $\lambda_{\max }\left(\log \varepsilon_{\max }\right): 243 \mathrm{~nm}(4.40), 315 \mathrm{~nm}(4.09), 354 \mathrm{~nm}$ (4.45). - IR (KBr) $v_{\max }=3405-3200,1722,1710,1625,1500,1220,1034,810 \mathrm{~cm}^{-1}$. - ${ }^{1} \mathrm{H}-\mathrm{NMR}$ (Measured in $\mathrm{CDCl}_{3}$ ) $\left(\right.$ See Table 2) . - ${ }^{13} \mathrm{C}-\mathrm{NMR}$ (Measured in $\left.\mathrm{CDCl}_{3}\right)\left(\right.$ see Table 1). - HRMS: $m / z=448.1380[\mathrm{M}]^{+}$(calcd. for $\mathrm{C}_{26} \mathrm{H}_{24} \mathrm{O}_{7}:$ 448.1382).

\subsection{Antibacterial Assay}

Antibacterial activity was determined by the paper disk method. A paper disk $(\Phi 6 \mathrm{~mm}$, from Whatman number one filter paper), with the sample was incubated on an agar plate containing E. coli, S. aureus, or P. vulgaris at $25^{\circ} \mathrm{C}$. Paper discs containing Amikacin $(30 \mu \mathrm{g})$, Vancomycin $(30 \mu \mathrm{g})$ and Penicilin $(10 \mu \mathrm{g})$, respectively, were used as positive control. The result recorded for each bioassay was the average of three tests.

\section{Results and Discussion}

\subsection{Structural Elucidation of Compounds $\mathbf{1}$ and $\mathbf{4}$}

Compound 1 was obtained as white powder. Its molecular formula was derived as $\mathrm{C}_{32} \mathrm{H}_{36} \mathrm{O}_{11}$ by the high resolution-FABMS (HRFABMS) spectrum, showing an $[\mathrm{M}]^{+}$ion at $\boldsymbol{m} / \mathbf{z}=596.2120$, and broad band-decoupled ${ }^{13} \mathrm{C}$-NMR spectrum ( 32 carbon signals). The IR spectrum disclosed absorption bands due to $\delta$-lactone carbonyl $\left(1724 \mathrm{~cm}^{-1}\right)$, aromatic ring $\left(1625,1600,1504 \mathrm{~cm}^{-1}\right)$ and aromatic C-O $\left(1222 \mathrm{~cm}^{-1}\right)$. UV spectrum showed absorption maxima at 244,315 , and $355 \mathrm{~nm}$. The IR and UV bands indicated the coumestan nature of 1 (Kouam et al. 2007; Mabry and Markham, 1975). The ${ }^{1} \mathrm{H}$ - and ${ }^{13} \mathrm{C}-\mathrm{NMR}$ spectroscopic data of $\mathbf{1}$ (Table 1 and 2) revealed the presence of a sugar residue in addition to a coumestan aglycone moiety. Upon acid hydrolysis (note 2), 1 afforded D-galactose and compound 4.

Compound 4 had the molecular formula $\mathrm{C}_{26} \mathrm{H}_{26} \mathrm{O}_{6}$ on the basis of the HREIMS, exhibiting an $[\mathrm{M}]^{+}$peak at $\boldsymbol{m} / \boldsymbol{z}=$ 434.1591, and ${ }^{13} \mathrm{C}-\mathrm{NMR}$ spectrum (Table 1) (26 carbon signals). A distortionless enhancement by polarization transfer (DEPT) NMR experiment permitted differentiation of the 26 resonances into four methyl, three methylene, six methine, and thirteen quaternary carbons. Its UV and IR spectra were similar to those of other coumestans. The ${ }^{1} \mathrm{H}-\mathrm{NMR}$ spectrum(Table 2) displayed two para-coupled aromatic protons at $\delta_{\mathrm{H}} 7.76(\mathrm{~d}, 1 \mathrm{H}, J=$ $1.2 \mathrm{~Hz}, \mathrm{H}-1)$ and $6.96(\mathrm{~d}, 1 \mathrm{H}, J=1.2 \mathrm{~Hz}, \mathrm{H}-4)$. It also showed a peak for another para-coupled protons at $\delta_{\mathrm{H}} 7.02$ $(\mathrm{d}, 1 \mathrm{H}, J=1.7 \mathrm{~Hz}, \mathrm{H}-7), 6.97(\mathrm{~d}, 1 \mathrm{H}, J=1.7 \mathrm{~Hz}, \mathrm{H}-10)$. In the ${ }^{1} \mathrm{H}-\mathrm{NMR}$ spectrum, further signals were observed that showed the presence of one methoxy group $[3.99(3 \mathrm{H}, \mathrm{s})]$, two hydroxyl units $[9.55(1 \mathrm{H}, \mathrm{s})$ and $5.34(1 \mathrm{H}, \mathrm{s})]$, a prenyl unit [3.21(2H, d, $J=6.9 \mathrm{~Hz}, \mathrm{H}-1$ "), $5.02(1 \mathrm{H}, \mathrm{t}, J=6.9 \mathrm{~Hz}, \mathrm{H}-2 "), 1.81(3 \mathrm{H}, \mathrm{s}, \mathrm{H}-4 ")$, and 1.79 (3H, s, H-5")], and a 4'-hydroxy-3'-methyl-butenyl residue [3.13 (2H, d, $J=8.0 \mathrm{~Hz}, \mathrm{H}-1$ '), 5.09 (1H, t, $J=8.0 \mathrm{~Hz}, \mathrm{H}-$ $\left.2^{\prime}\right), 4.55\left(2 \mathrm{H}, \mathrm{s}, \mathrm{H}-4^{\prime}\right)$, and $\left.1.78\left(3 \mathrm{H}, \mathrm{s}, \mathrm{H}-5^{\prime}\right)\right]$. In the NOESY spectrum, cross peak was observed from $\mathrm{H}_{2}-4^{\prime}$ to $\mathrm{H}-2$ ', confirming that the relative configuration was $E$. In the heteronuclear multiple bond correlation (HMBC) spectrum, the cross peaks from the proton at $\delta_{\mathrm{H}} 9.55$ to C-3, from the proton at $\delta_{\mathrm{H}} 5.34$ to C-4', and from the proton at $\delta_{\mathrm{H}} 3.99$ to $\mathrm{C}-9$, confirmed that two hydroxyl moieties were attached to $\mathrm{C}-3$ and $\mathrm{C}-4$ ', one methoxy to C-9. The position of the prenyl group was confirmed by HMBC experiment, which showed correlation between a vinylic proton $\mathrm{H}-2$ " and $\mathrm{C}-8$, furthermore, the methylene protons $\mathrm{H}_{2}-1$ " of the prenyl substituent showed correlations with $\mathrm{C}-8, \mathrm{C}-7$, and C-9. Moreover, in $\mathrm{HMBC}$ spectrum, the cross peaks from the proton at $\delta_{\mathrm{H}}$ 
5.09(H-2') to C-2, from the proton at $\delta_{\mathrm{H}} 3.13$ (H-1') to $\mathrm{C}-2, \mathrm{C}-1$, and $\mathrm{C}-3$ confirmed that the 4'-hdroxy-3'-methyl-butenyl residue was located at C-2. The complete structural elucidation of 4 was derived from the chemical shifts and coupling constant of the ${ }^{1} \mathrm{H}-\mathrm{NMR}$ spectrum and from detailed spectral analysis of HMQC, HMBC experiments (Table 3). Consequently, the structure of $\mathbf{4}$ was determined as 3-hydroxy-9-methoxy- 2-[2'(E)-4'-hydroxy-3'-methylbutenyl]-8-isoprenylcoumestan (4) (see Fig. 1).

The molecular formula of $\mathbf{1}$ indicated that it consisted of one mole each of $\mathbf{4}$ and D-galactose. For clarification of the location of the sugar moiety in compound 1 , the ${ }^{13} \mathrm{C}-\mathrm{NMR}$ and $\mathrm{HMBC}$ spectra were inspected. In the ${ }^{13} \mathrm{C}-\mathrm{NMR}$ spectrum, the shift values for the carbons of the aglycone residue were in agreement with the corresponding data of compound 4, except for the C- 4', which was significantly downfield. Furthermore, in the HMBC spectrum of $\mathbf{1}$, the anomeric proton signal at $\delta=4.81(\mathrm{~d}, J=7.8 \mathrm{~Hz}, \mathrm{H}-1$ ",') exhibited three-bond-coupled carbon signal at $\delta=80.4$ (C-4'). These results indicated that the C-4' hydroxyl group of 3-hydroxy-9-methoxy- 2-[2'(E)-4'-hydroxy-3'-methylbutenyl]-8-isoprenyl coumestan was bound to a sugar through glycosidic linkage. The $J$ value $(7.8 \mathrm{~Hz})$ of the anomeric proton indicated that galactose moiety was linked via a $\beta$ - linkage. Consequently, the structure of 1 was determined as 3-hydroxy-9-methoxy2-[2'(E)-3'-methyl- 4'-O- $\beta$-D-galactopyranosylbutenyl]-8-isoprenylcoumestan (1) (see Fig 1).

\subsection{Structural Elucidation of Compounds $\mathbf{2}$ and $\mathbf{5}$}

Compound 2, obtained as white powder, had a molecular formula of $\mathrm{C}_{32} \mathrm{H}_{34} \mathrm{O}_{12}$ on the basis of its HRFABMS $\left(m / z=610.1912[\mathrm{M}]^{+}\right)$and ${ }^{13} \mathrm{C}-\mathrm{NMR}$ data (Table 2) (32 signals). The IR and UV bands indicated the coumestan nature of 2. Furthermore, the ${ }^{1} \mathrm{H}$ - and ${ }^{13} \mathrm{C}-\mathrm{NMR}$ spectroscopic data of $\mathbf{2}$ (Table 1 and 2) revealed the presence of a sugar residue in addition to a coumestan aglycone moiety. Upon acid hydrolysis (note 2), 2 afforded D-glucose and compound $\mathbf{5}$.

Compound 5 had the molecular formula $\mathrm{C}_{26} \mathrm{H}_{24} \mathrm{O}_{7}$ on the basis of the HREIMS, exhibiting an [M] $]^{+}$peak at $m / z=$ 448.1381, and ${ }^{13} \mathrm{C}-\mathrm{NMR}$ spectrum (Table 1) (26 carbon signals). Its UV and IR spectra were almost similar to those of compound 4. The NMR spectra of 5 (Table 1 and 2) resembled those of 4, except for the presence of an 4"-oxo-isopentenyl group signals $\left[3.18\left(2 \mathrm{H}, \mathrm{d}, J=7.0 \mathrm{~Hz}, \mathrm{H}_{2}-1\right.\right.$ "), $5.01(1 \mathrm{H}, \mathrm{t}, J=7.0 \mathrm{~Hz}, \mathrm{H}-2$ "), $9.03(1 \mathrm{H}, \mathrm{s}$, H- 4"), and $1.78\left(3 \mathrm{H}, \mathrm{s}, \mathrm{H}_{3}-5\right.$ ")] instead of isopentenyl signals in 4 (Table 1 and 2). In the NOESY spectrum, cross peak was observed from H-4" to H-2". Based on the chemical shifts and coupling constant of the ${ }^{1} \mathrm{H}-\mathrm{NMR}$ spectrum and detailed spectral analysis of HMQC and HMBC experiments (Table 3) the complete structural elucidation of $\mathbf{5}$ was derived as 3-hydroxy-9-methoxy-2-[2'(E)-4'-hydroxy-3'-methylbutenyl]-8-[2'" $(E)$ -3"-methyl-4"-oxobutenyl]coumestan(5) (see Fig. 1).

The molecular formula of $\mathbf{2}$ indicated that it consisted of one mole each of $\mathbf{5}$ and D-glucose. Comparison of ${ }^{13} \mathrm{C}-\mathrm{NMR}$ data of $\mathbf{2}$ with those of 3-hydroxy-9-methoxy-2-[2'(E)-4'-hydroxy-3'-methylbutenyl] $-8-[2$ " $(E)-3$ "'-methyl-4"-oxobutenyl]coumestan (Table 1) combined with the HMBC spectrum showing three-bond-coupled signal between the anomeric proton signal at $\delta=4.34(\mathrm{~d}, J=7.7 \mathrm{~Hz})$ and carbon signal at $\delta=$ 80.5 (C-4') showed that the C-4' hydroxyl group of the aglycone moiety is connected to the glucose molecule through a glycosidic bond. The configuration of the D-glucopyranosyl unit was regarded to be $\beta$ by the $J$ value of of its anomeric proton signal. The structure of $\mathbf{2}$ was finally concluded as 3- hydroxy-9-methoxy2-[2' $(E)$-3'-methyl- 4'-O- $\beta$-D-glucopyranosylbutenyl]-8-[2"'(E)-3"'-methyl-4"'-oxo-butenyl]coumestan (2) (see Fig 1).

\subsection{Structural Elucidation of Compounds $\mathbf{3}$ and $\mathbf{6}$}

Compound 3 was obtained as white powder. Its molecular formula was derived as $\mathrm{C}_{32} \mathrm{H}_{34} \mathrm{O}_{12}$ by the HRFABMS spectrum, showing an $[\mathrm{M}]^{+}$ion at $m / z=610.1912$, and broad band-decoupled ${ }^{13} \mathrm{C}-\mathrm{NMR}$ spectrum (Table 1$)$ (32 carbon signals). Its IR, UV and NMR data indicated that it was a coumestan glycoside. Acid hydrolysis (note 2) yielded D-glucose along with compound 6.

Compound 6 had the molecular formula $\mathrm{C}_{26} \mathrm{H}_{24} \mathrm{O}_{7}$ on the basis of the HREIMS, exhibiting an [M] $]^{+}$peak at $m / z=$ 448.1380, and ${ }^{13} \mathrm{C}-\mathrm{NMR}$ spectrum(Table 1) (26 carbon signals). Its UV and IR spectra were almost similar to those of compound 5. The ${ }^{1} \mathrm{H}-\mathrm{NMR}$ spectrum displayed two ortho-coupled aromatic protons at $\delta 7.79(1 \mathrm{H}, \mathrm{d}, J=$ $8.2 \mathrm{~Hz}, \mathrm{H}-1)$ and $6.96(1 \mathrm{H}, \mathrm{d}, J=8.2 \mathrm{~Hz}, \mathrm{H}-2)$. In para position were another two protons at $\delta 7.01(1 \mathrm{H}, \mathrm{d}, J=$ $1.6 \mathrm{~Hz}, \mathrm{H}-7)$ and $6.97(1 \mathrm{H}, \mathrm{d}, J=1.6 \mathrm{~Hz}, \mathrm{H}-10)$. In the ${ }^{1} \mathrm{H}-\mathrm{NMR}$ spectrum of 6 , further signals were observed that showed the presence of two hydroxy, one methoxy, one 4'-hydroxy-3'-methyl-butenyl and one 3"-methyl-4"'-oxo-butenyl moieties(Table 2). In the NOESY spectrum, cross peak was observed from H-4' to H-2', from H-4" to H-2" and from H-1 to H-2. Based on the chemical shifts and coupling constant of the ${ }^{1} \mathrm{H}-\mathrm{NMR}$ spectrum and detailed spectral analysis of HMQC, HMBC experiments (Table 3) the complete structural elucidation of 6 was derived as 3-hydroxy-9-methoxy-4-[2'(E)-4'-hydroxy-3'-methylbutenyl]- 
8-[2"(E)-3"-methyl-4"-oxo-butenyl]coumestan (6)(see Fig. 1).

The molecular formula of $\mathbf{3}$ indicated that it consisted of one mole each of $\mathbf{6}$ and D-glucose. The $\beta$ configuration of the D-glucopyranosyl moiety was deduced from the coupling value of the anomeric proton signal at $4.35 \mathrm{ppm}$ $(J=7.9 \mathrm{~Hz})$. The position of the glycosyl moiety in $\mathbf{3}$ was decided by the comparison of ${ }^{13} \mathrm{C}-\mathrm{NMR}$ data of $\mathbf{3}$ with those of $\mathbf{6}$ (Table 1), and the HMBC spectrum in which three-bond-coupled signal between the anomeric proton signal and carbon signal at $\delta=80.1$ (C-4') was observed. In conclusion, the structure of $\mathbf{3}$ was determined to be 3- hydroxy-9-methoxy-4-[2'(E)-3'-methyl-4'-O- $\beta$-D-gluopyranosylbutenyl]-8-[2"'(E)-3"'-methyl-4"-oxo-butenyl] -coumestan (3) (see Fig 1).

\subsection{Antibacterial Assay}

Compounds 1 - $\mathbf{6}$ showed antimicrobial activities against E. coli, S. aureus, and P. vulgaris at the concentration of $13 \mu \mathrm{g} / \mathrm{dis}$ (Table 4 ).

\section{Conclusion}

Picralima nitida is known as a rich source of alkaloids. Some of them have been reported to show biological activities (Corbett, et al. 1996; Fakeye et al. 2000; Ramirez et al. 2003; Ezeamuzie et al. 1994). However, this paper preliminarily studies the neutral constituents of $P$. nitida roots. The separated products are flavonoids. The use of the roots of $P$. nitida as anti-infective agent may be explained by the presence of antimicrobial coumestan derivatives.

\section{References}

Adjanohoun, E.J., Aboubakar, N., Dramane, K., Ebot, M.E., Ekpere, J.A., Enow-Orock, E.G., Focho, D., Gbilé, Z.O., Kamanyi, A., Kamsu, K.J., Keita, A., Mbenkum, T., Mbi, C.N., Mbiele, A.L., Mbome, I.L., Mubiru, N.K., Nancy, W.L., Nkongmeneck, B., Satabié, B., Sofowora, A., Tamze, V. \& Wirmum, C.K. (1996). Contribution to ethnobotanical and floristic studies in Cameroon. CSTR/OUA, Cameroon. $641 \mathrm{pp}$.

Corbett, A.D., Menzies, J.R.W., Macdonald, A., Paterson, S.J. and Duwiejua, M. (1996). The opioid activity of akuammine, akuammicine and akuammidine: alkaloids from Picralima nitida (fam. Apocynaceae). British Journal of Pharmacology, 119, 334 Supplement S.

Ezeamuzie, I.C., Ojinnaka, M.C., Uzogara, E.O. and Oji, S.E. (1994). Anti-inflammatory, antipyretic and anti-malarial activities of a West African medicinal plant - Picralima nitida. African Journal of Medicine and Medical Sciences, 23, 85-90.

Fakeye, T.O., Itiola, O.A. and Odelola, H.A. (2000). Evaluation of the antimicrobial property of the stem bark of Picralima nitida (Apocynaceae). Phytotherapy Research, 14, 368-370.

Kazie N., Kouam, J. Tane,P. Kuete, V. Watchueng, J. and Fomum, Z. T. (2009). Coumestan Glcosides from the Stem Bark of Cylicodiscus gabunensis. Natural Product communications, 4, 931-934.

Kouam, J., Tane, P., Meli, A., Noundou, S.X., Muhammad, I.C. and Fomum, Z.T. (2007). Coumestoside A, Coumestoside B and Erythrodiside A, Three Glcosides from Cylicodiscus gabunensis (Mimmosaceae). Natural Product communications, 2, 835-840.

Kouitcheu, L. B., Kouam, J., Atangana, P. and Etoa, F. X. (2008). Phytochemical screening and toxicological profile of methanolic extract of Picralima nitida fruit-rind(Apocynaceae). Toxicological \& Environmental Chemistry, 90, 815-828.

Mabry,T.J. and Markham, K. R. (1975). In The Flavonoids, Part 1; J. B. Harbone, T. J.Mabry, (Eds) Academic Press: New York, pp 78-126.

Ramirez, A. and García-Ribio, S. (2003). Current progress in the chemistry and pharmacology of akuammiline alkaloids. Current Medicinal Chemistry, 10, 1891-1915.

\section{Notes}

Note 1. In memoriam

Note 2. The reason of this acidic treatment was to isolate and identify separately the nature of sugar and aglycone moieties. 
Table 1. The ${ }^{13} \mathrm{C}-\mathrm{NMR}\left(\delta_{\mathrm{c}}\right.$ in ppm, $\left.125 \mathrm{MHz}\right)$ Data of Compounds 1 - 6

\begin{tabular}{|c|c|c|c|c|c|c|}
\hline \multirow{3}{*}{ Position } & \multicolumn{6}{|c|}{ Compounds } \\
\hline & 1 & 2 & 3 & 4 & 5 & 6 \\
\hline & $\delta_{\mathrm{c}}(\mathrm{DEPT})$ & $\delta_{\mathrm{c}}(\mathrm{DEPT})$ & $\delta_{\mathrm{c}}(\mathrm{DEPT})$ & $\delta_{\mathrm{c}}(\mathrm{DEPT})$ & $\delta_{\mathrm{c}}(\mathrm{DEPT})$ & $\delta_{\mathrm{c}}(\mathrm{DEPT})$ \\
\hline 1 & $121.9(\mathrm{CH})$ & $122.2(\mathrm{CH})$ & $122.2(\mathrm{CH})$ & $121.7(\mathrm{CH})$ & $122.2(\mathrm{CH})$ & $122.2(\mathrm{CH})$ \\
\hline 2 & $111.4(\mathrm{C})$ & $110.2(\mathrm{C})$ & $114.1(\mathrm{CH})$ & $111.2(\mathrm{C})$ & $110.3(\mathrm{C})$ & $114.2(\mathrm{CH})$ \\
\hline 3 & $153.9(\mathrm{C})$ & $154.2(\mathrm{C})$ & $154.0(\mathrm{C})$ & $153.8(\mathrm{C})$ & $154.1(\mathrm{C})$ & $153.8(\mathrm{C})$ \\
\hline 4 & $113.9(\mathrm{CH})$ & $113.2(\mathrm{CH})$ & 109.1(C) & $113.5(\mathrm{CH})$ & $113.6(\mathrm{CH})$ & 109.2(C) \\
\hline $4 a$ & $157.5(\mathrm{C})$ & $157.4(\mathrm{C})$ & $157.4(\mathrm{C})$ & $157.4(\mathrm{C})$ & $157.4(\mathrm{C})$ & $157.3(\mathrm{C})$ \\
\hline 6 & $163.2(\mathrm{C})$ & $163.5(\mathrm{C})$ & $163.4(\mathrm{C})$ & $163.2(\mathrm{C})$ & $163.5(\mathrm{C})$ & $163.4(\mathrm{C})$ \\
\hline $6 a$ & $113.5(\mathrm{C})$ & $113.6(\mathrm{C})$ & $113.6(\mathrm{C})$ & $113.5(\mathrm{C})$ & $113.5(\mathrm{C})$ & $113.5(\mathrm{C})$ \\
\hline $6 \mathrm{~b}$ & $118.4(\mathrm{C})$ & $118.5(\mathrm{C})$ & $118.5(\mathrm{C})$ & $118.2(\mathrm{C})$ & $118.4(\mathrm{C})$ & $118.5(\mathrm{C})$ \\
\hline 7 & $123.7(\mathrm{CH})$ & $123.4(\mathrm{CH})$ & $123.5(\mathrm{CH})$ & $123.5(\mathrm{CH})$ & $123.4(\mathrm{CH})$ & $123.4(\mathrm{CH})$ \\
\hline 8 & $122.0(\mathrm{C})$ & 121.7(C) & 121.7(C) & $121.9(\mathrm{C})$ & $121.6(\mathrm{C})$ & $121.8(\mathrm{C})$ \\
\hline 9 & $152.6(\mathrm{C})$ & $152.8(\mathrm{C})$ & $152.8(\mathrm{C})$ & $152.5(\mathrm{C})$ & $152.8(\mathrm{C})$ & $152.8(\mathrm{C})$ \\
\hline 10 & $99.1(\mathrm{CH})$ & $98.9(\mathrm{CH})$ & $98.8(\mathrm{CH})$ & 99.2(CH) & $98.8(\mathrm{CH})$ & $98.6(\mathrm{CH})$ \\
\hline $10 \mathrm{a}$ & $157.9(\mathrm{C})$ & 158.1(C) & $158.0(\mathrm{C})$ & $157.8(\mathrm{C})$ & $158.0(\mathrm{C})$ & $157.8(\mathrm{C})$ \\
\hline $11 \mathrm{a}$ & $160.0(\mathrm{C})$ & $159.8(\mathrm{C})$ & $159.8(\mathrm{C})$ & $159.9(\mathrm{C})$ & $159.8(\mathrm{C})$ & 159.7 (C) \\
\hline $11 \mathrm{~b}$ & $103.9(\mathrm{C})$ & $104.1(\mathrm{C})$ & $104.0(\mathrm{C})$ & $103.9(\mathrm{C})$ & $104.2(\mathrm{C})$ & $103.9(\mathrm{C})$ \\
\hline $1 '$ & $30.5\left(\mathrm{CH}_{2}\right)$ & $30.5\left(\mathrm{CH}_{2}\right)$ & $30.3\left(\mathrm{CH}_{2}\right)$ & $30.4\left(\mathrm{CH}_{2}\right)$ & $30.4\left(\mathrm{CH}_{2}\right)$ & $30.1\left(\mathrm{CH}_{2}\right)$ \\
\hline $2^{\prime}$ & $122.9(\mathrm{CH})$ & $123.3(\mathrm{CH})$ & $123.1(\mathrm{CH})$ & $122.8(\mathrm{CH})$ & $123.3(\mathrm{CH})$ & $123.1(\mathrm{CH})$ \\
\hline $3^{\prime}$ & $131.0(\mathrm{C})$ & $130.9(\mathrm{C})$ & 130.9(C) & $130.9(\mathrm{C})$ & $130.8(\mathrm{C})$ & $130.8(\mathrm{C})$ \\
\hline $4^{\prime}$ & $80.4\left(\mathrm{CH}_{2}\right)$ & $80.5\left(\mathrm{CH}_{2}\right)$ & $80.1\left(\mathrm{CH}_{2}\right)$ & 80. $\left(\mathrm{CH}_{2}\right)$ & $78.2\left(\mathrm{CH}_{2}\right)$ & 77.9 $\left(\mathrm{CH}_{2}\right)$ \\
\hline 5 & $25.8\left(\mathrm{CH}_{3}\right)$ & $25.6\left(\mathrm{CH}_{3}\right)$ & $25.4\left(\mathrm{CH}_{3}\right)$ & $25.7(\mathrm{CH} 3)$ & $25.5\left(\mathrm{CH}_{3}\right)$ & $25.3\left(\mathrm{CH}_{3}\right)$ \\
\hline 9- $\mathrm{OCH}_{3}$ & $56.5\left(\mathrm{CH}_{3}\right)$ & $56.6\left(\mathrm{CH}_{3}\right)$ & $56.6\left(\mathrm{CH}_{3}\right)$ & $56.7\left(\mathrm{CH}_{3}\right)$ & $56.5\left(\mathrm{CH}_{3}\right)$ & $56.4\left(\mathrm{CH}_{3}\right)$ \\
\hline $1 "$ & $29.8\left(\mathrm{CH}_{2}\right)$ & $30.1\left(\mathrm{CH}_{2}\right)$ & $30.1\left(\mathrm{CH}_{2}\right)$ & $30.1\left(\mathrm{CH}_{2}\right)$ & $30.0\left(\mathrm{CH}_{2}\right)$ & $30.1\left(\mathrm{CH}_{2}\right)$ \\
\hline $2 "$ & $122.7(\mathrm{CH})$ & $123.0(\mathrm{CH})$ & $123.0(\mathrm{CH})$ & $123.0(\mathrm{CH})$ & $123.0(\mathrm{CH})$ & $123.0(\mathrm{CH})$ \\
\hline $3 "$ & $130.1(\mathrm{C})$ & 130.4(C) & $130.5(\mathrm{C})$ & 130.4(C) & $130.4(\mathrm{C})$ & $130.4(\mathrm{C})$ \\
\hline 4" & $18.2\left(\mathrm{CH}_{3}\right)$ & $204.8(\mathrm{CH})$ & $204.8(\mathrm{CH})$ & $18.1\left(\mathrm{CH}_{3}\right)$ & $204.7(\mathrm{CH})$ & $204.7(\mathrm{CH})$ \\
\hline $5 "$ & $25.3\left(\mathrm{CH}_{3}\right)$ & $25.4\left(\mathrm{CH}_{3}\right)$ & $25.3\left(\mathrm{CH}_{3}\right)$ & $25.4\left(\mathrm{CH}_{3}\right)$ & $25.4\left(\mathrm{CH}_{3}\right)$ & $25.3\left(\mathrm{CH}_{3}\right)$ \\
\hline $1, \%$ & $100.1(\mathrm{CH})$ & $101.8(\mathrm{CH})$ & $100.7(\mathrm{CH})$ & & & \\
\hline $2, \%$ & $73.6(\mathrm{CH})$ & $74.5(\mathrm{CH})$ & $74.5(\mathrm{CH})$ & & & \\
\hline $3, \%$ & $76.9(\mathrm{CH})$ & $77.9(\mathrm{CH})$ & $78.0(\mathrm{CH})$ & & & \\
\hline $4, "$, & $70.2(\mathrm{CH})$ & $71.3(\mathrm{CH})$ & $71.2(\mathrm{CH})$ & & & \\
\hline 5, & $76.7(\mathrm{CH})$ & $77.6(\mathrm{CH})$ & $77.5(\mathrm{CH})$ & & & \\
\hline $6 \%$ & $61.3\left(\mathrm{CH}_{2}\right)$ & $63.5\left(\mathrm{CH}_{2}\right)$ & $63.4\left(\mathrm{CH}_{2}\right)$ & & & \\
\hline
\end{tabular}


Table 2. The ${ }^{1} \mathrm{H}-\mathrm{NMR}$ ( $\delta_{\mathrm{H}}$ in ppm, 500MHz) Data of Compounds 1 - 6

\begin{tabular}{|c|c|c|c|c|c|c|}
\hline \multirow{3}{*}{ Position } & \multicolumn{6}{|c|}{ Compounds } \\
\hline & 1 & 2 & 3 & 4 & 5 & 6 \\
\hline & $\delta_{\mathrm{H}}($ mult,$J)$ & $\delta_{\mathrm{H}}($ mult,$J)$ & $\delta_{\mathrm{H}}($ mult, $J$ ) & $\delta_{\mathrm{H}}($ mult,$J)$ & $\delta_{\mathrm{H}}($ mult,$J)$ & $\delta_{\mathrm{H}}($ mult,$J$ ) \\
\hline 1 & $7.77(1 \mathrm{H}, \mathrm{d}, 1.2)$ & $7.79(1 \mathrm{H}, \mathrm{d}, 1.5)$ & $7.80(1 \mathrm{H}, \mathrm{d}, 8.1)$ & $7.76(1 \mathrm{H}, \mathrm{d}, 1.2)$ & $7.78(1 \mathrm{H}, \mathrm{d}, 1.4)$ & $7.79(1 \mathrm{H}, \mathrm{d}, 8.2)$ \\
\hline 2 & & & $6.97(1 \mathrm{H}, \mathrm{d}, 8.1)$ & & & $6.96(1 \mathrm{H}, \mathrm{d}, 8.2)$ \\
\hline 4 & $6.95(1 \mathrm{H}, \mathrm{d}, 1.2)$ & $6.96(1 \mathrm{H}, \mathrm{d}, 1.5)$ & & $6.96(1 \mathrm{H}, \mathrm{d}, 1.2)$ & $6.95(1 \mathrm{H}, \mathrm{d}, 1.4)$ & \\
\hline 7 & 7.04(1H, d, 1.6) & $7.03(1 \mathrm{H}, \mathrm{d}, 1.7)$ & $7.03(1 \mathrm{H}, \mathrm{d}, 1.8)$ & $7.02(1 \mathrm{H}, \mathrm{d}, 1.7)$ & $7.03(1 \mathrm{H}, \mathrm{d}, 1.6)$ & $7.01(1 \mathrm{H}, \mathrm{d}, 1.6)$ \\
\hline 10 & $6.98(1 \mathrm{H}, \mathrm{d}, 1.6)$ & $6.97(1 \mathrm{H}, \mathrm{d}, 1.7)$ & $6.98(1 \mathrm{H}, \mathrm{d}, 1.8)$ & $6.97(1 \mathrm{H}, \mathrm{d}, 1.7)$ & $6.98(1 \mathrm{H}, \mathrm{d}, 1.6)$ & $6.97(1 \mathrm{H}, \mathrm{d}, 1.6)$ \\
\hline 1 ' & $3.15(2 \mathrm{H}, \mathrm{d}, 8.1)$ & $3.15(2 \mathrm{H}, \mathrm{d}, 8.2)$ & $3.14(2 \mathrm{H}, \mathrm{d}, 8.2)$ & $3.13(2 \mathrm{H}, \mathrm{d}, 8.0)$ & $3.14(2 \mathrm{H}, \mathrm{d}, 8.0)$ & $3.14(2 \mathrm{H}, \mathrm{d}, 8.2)$ \\
\hline $2^{\prime}$ & $5.10(1 \mathrm{H}, \mathrm{t}, 8.1)$ & $5.12(1 \mathrm{H}, \mathrm{t}, 8.2)$ & $5.11(1 \mathrm{H}, \mathrm{t}, 8.2)$ & $5.09(1 \mathrm{H}, \mathrm{t}, 8.0)$ & $5.10(1 \mathrm{H}, \mathrm{t}, 8.0)$ & $5.11(1 \mathrm{H}, \mathrm{t}, 8.2)$ \\
\hline $4^{\prime}$ & $5.80(2 \mathrm{H}, \mathrm{s})$ & $5.82(2 \mathrm{H}, \mathrm{s})$ & $5.81(2 \mathrm{H}, \mathrm{s})$ & $4.55(2 \mathrm{H}, \mathrm{s})$ & $4.54(2 \mathrm{H}, \mathrm{s})$ & $4.51(2 \mathrm{H}, \mathrm{s})$ \\
\hline 5 , & $1.78(3 \mathrm{H}, \mathrm{s})$ & $1.78(3 \mathrm{H}, \mathrm{s})$ & $1.78(3 \mathrm{H}, \mathrm{s})$ & $1.78(3 \mathrm{H}, \mathrm{s})$ & $1.76(3 \mathrm{H}, \mathrm{s})$ & $1.77(3 \mathrm{H}, \mathrm{s})$ \\
\hline $1 "$ & $3.20(2 \mathrm{H}, \mathrm{d}, 7.0)$ & $3.18(2 \mathrm{H}, \mathrm{d}, 7.1)$ & $3.19(2 \mathrm{H}, \mathrm{d}, 7.0)$ & $3.21(2 \mathrm{H}, \mathrm{d}, 6.9)$ & $3.18(2 \mathrm{H}, \mathrm{d}, 7.0)$ & $3.20(2 \mathrm{H}, \mathrm{d}, 7.1)$ \\
\hline $2 "$ & $5.01(1 \mathrm{H}, \mathrm{t}, 7.2)$ & $5.02(1 \mathrm{H}, \mathrm{t}, 7.1)$ & $5.01(1 \mathrm{H}, \mathrm{t}, 7.0)$ & $5.02(1 \mathrm{H}, \mathrm{t}, 6.9)$ & $5.01(1 \mathrm{H}, \mathrm{t}, 7.0)$ & $5.02(1 \mathrm{H}, \mathrm{t}, 7.1)$ \\
\hline $4 "$ & $1.82(3 \mathrm{H}, \mathrm{s})$ & $9.04(1 \mathrm{H}, \mathrm{s})$ & $9.01(1 \mathrm{H}, \mathrm{s})$ & $1.81(3 \mathrm{H}, \mathrm{s})$ & $9.03(1 \mathrm{H}, \mathrm{s})$ & $9.02(1 \mathrm{H}, \mathrm{s})$ \\
\hline $5 "$ & $1.78(3 \mathrm{H}, \mathrm{s})$ & $1.78(3 \mathrm{H}, \mathrm{s})$ & $1.78(3 \mathrm{H}, \mathrm{s})$ & $1.79(3 \mathrm{H}, \mathrm{s})$ & $1.78(3 \mathrm{H}, \mathrm{s})$ & $1.76(3 \mathrm{H}, \mathrm{s})$ \\
\hline $1, "$ & $4.81(1 \mathrm{H}, \mathrm{d}, 7.8)$ & $4.34(1 \mathrm{H}, \mathrm{d}, 7.7)$ & $4.35(1 \mathrm{H}, \mathrm{d}, 7.9)$ & & & \\
\hline $2 "$, & $3.22(1 \mathrm{H}, \mathrm{dd}, 8.6,7.9)$ & $3.39(1 \mathrm{H}, \mathrm{dd}, 8.2,7.8)$ & $3.37(1 \mathrm{H}, \mathrm{dd}, 8.4,7.9)$ & & & \\
\hline 3, & $3.41(1 \mathrm{H}, \mathrm{m})$ & $3.25(1 \mathrm{H}, \mathrm{m})$ & $3.26(1 \mathrm{H}, \mathrm{m})$ & & & \\
\hline $4, "$ & $3.40(1 \mathrm{H}, \mathrm{dd}, 3.5,3.6)$ & $3.22(1 \mathrm{H}, \mathrm{dd}, 7.4,7.6)$ & $3.22(1 \mathrm{H}, \mathrm{dd}, 3.4,3.6)$ & & & \\
\hline 5, & $3.32(1 \mathrm{H}, \mathrm{m})$ & $3.54(1 \mathrm{H}, \mathrm{m})$ & $3.55(1 \mathrm{H}, \mathrm{m})$ & & & \\
\hline 6, & $3.75(1 \mathrm{H}, \mathrm{dd}, 11.4,5.6)$ & $4.51(1 \mathrm{H}, \mathrm{dd}, 10.3,5.4)$ & $4.52(1 \mathrm{H}, \mathrm{dd}, 11.3,5.4)$ & & & \\
\hline & $3.51(1 \mathrm{H}, \mathrm{d}, 11.4)$ & $4.54(1 \mathrm{H}, \mathrm{dd}, 10.3,5.1)$ & $4.55(1 \mathrm{H}, \mathrm{d}, 11.3)$ & & & \\
\hline $3-\mathrm{OH}$ & $9.57(1 \mathrm{H}, \mathrm{s})$ & $9.58(1 \mathrm{H}, \mathrm{s})$ & $9.54(1 \mathrm{H}, \mathrm{s})$ & $9.55(1 \mathrm{H}, \mathrm{s})$ & $9.55(1 \mathrm{H}, \mathrm{s})$ & $9.53(1 \mathrm{H}, \mathrm{s})$ \\
\hline $9-\mathrm{OCH}_{3}$ & $3.98(3 \mathrm{H}, \mathrm{s})$ & $4.02(3 \mathrm{H}, \mathrm{s})$ & $4.01(3 \mathrm{H}, \mathrm{s})$ & $3.99(3 \mathrm{H}, \mathrm{s})$ & $4.00(3 \mathrm{H}, \mathrm{s})$ & $4.01(3 \mathrm{H}, \mathrm{s})$ \\
\hline $4^{\prime}-\mathrm{OH}$ & $5.38(1 \mathrm{H}, \mathrm{s})$ & $5.37(1 \mathrm{H}, \mathrm{s})$ & $5.38(1 \mathrm{H}, \mathrm{s})$ & $5.34(1 \mathrm{H}, \mathrm{s})$ & $5.35(1 \mathrm{H}, \mathrm{s})$ & $5.37(1 \mathrm{H}, \mathrm{s})$ \\
\hline
\end{tabular}


Table 3. The HMQC and HMBC Data of Compounds 4 - 6

\begin{tabular}{|c|c|c|c|c|c|c|}
\hline \multirow{3}{*}{ Proton } & \multicolumn{6}{|c|}{ Compounds } \\
\hline & \multicolumn{2}{|r|}{4} & \multicolumn{2}{|r|}{5} & \multicolumn{2}{|r|}{6} \\
\hline & HMQC & HMBC & HMQC & $\mathrm{HMBC}$ & HMQC & HMBC \\
\hline 1 & $\mathrm{C}: 1$ & $\mathrm{C}: 2,11 \mathrm{~b}, 1^{\prime}, 3,4 \mathrm{a}, 11 \mathrm{a}$ & $\mathrm{C}: 1$ & $\mathrm{C}: 2,11 \mathrm{~b}, 1^{\prime}, 3,4 \mathrm{a}, 11 \mathrm{a}$ & $\mathrm{C}: 1$ & $\mathrm{C}: 2,11 \mathrm{~b}, 3,4 \mathrm{a}, 11 \mathrm{a}$ \\
\hline 2 & & & & & $\mathrm{C}: 2$ & $\mathrm{C}: 1,3,4,11 \mathrm{~b}$ \\
\hline 4 & $\mathrm{C}: 4$ & $\mathrm{C}: 3,4 \mathrm{a}, 1^{\prime}, 2,11 \mathrm{~b}$ & $\mathrm{C}: 4$ & $\mathrm{C}: 3,4 \mathrm{a}, 1^{\prime}, 2,11 \mathrm{~b}$ & & \\
\hline 7 & $\mathrm{C}: 7$ & C:6b:8,6a,1",10a,9 & $\mathrm{C}: 7$ & $\mathrm{C}: 6 \mathrm{~b}, 8,6 \mathrm{a}, 1 ", 10 \mathrm{a}, 9$ & C:7 & $\mathrm{C}: 6 \mathrm{~b}, 8,6 \mathrm{a}, 1 ", 10 \mathrm{a}, 9$ \\
\hline 10 & $\mathrm{C}: 10$ & $\mathrm{C}: 9,10 \mathrm{a}, 8,6 \mathrm{~b}$ & $\mathrm{C}: 10$ & $\mathrm{C}: 9,10 \mathrm{a}, 8,6 \mathrm{~b}$ & $\mathrm{C}: 10$ & $\mathrm{C}: 9,10 \mathrm{a}, 8,6 \mathrm{~b}$ \\
\hline $1 '$ & $\mathrm{C}: 1^{\prime}$ & $\mathrm{C}: 2,2^{\prime}, 3,1,3^{\prime}$ & $\mathrm{C}: 1^{\prime}$ & $\mathrm{C}: 2,2^{\prime}, 3,1,3^{\prime}$ & $\mathrm{C}: 1^{\prime}$ & $\mathrm{C}: 4,2^{\prime}, 3,4 \mathrm{a}, 3^{\prime}$ \\
\hline $2^{\prime}$ & $\mathrm{C}: 2^{\prime}$ & C:1',3',4',5',2 & $\mathrm{C}: 2^{\prime}$ & C:1',3', $4^{\prime}, 5^{\prime}, 2$ & $\mathrm{C}: 2$ & C:1',3', $4^{\prime}, 5^{\prime}, 4$ \\
\hline $4^{\prime}$ & C:4' & C:3',5',2' & C:4' & C:3',5',2', & C:4' & C:3',5',2' \\
\hline 5 & C:5 & C:3',4',2', & $\mathrm{C}: 5^{\prime}$ & C:3', $4^{\prime}, 2^{\prime}$ & C:5 & C:3', $4^{\prime}, 2^{\prime}$ \\
\hline $1 "$ & $\mathrm{C}: 1 ”$ & C:8,2",7,9,3" & $\mathrm{C}: 1 \%$ & C:8,2",7,9,3" & $\mathrm{C}: 1 "$ & C:8,2",7,9,3" \\
\hline $2 "$ & $\mathrm{C}: 2 "$ & C:1",3",4",5",8 & $\mathrm{C}: 2 "$ & C:1",3",4",5",8 & $\mathrm{C}: 2 "$ & C:1",3",4",5",8 \\
\hline 4" & C:4" & C:3",5",2" & $\mathrm{C}: 4 "$ & C:3",5",2" & $\mathrm{C}: 4 "$ & C:3",5",2" \\
\hline $5 "$ & C:5" & C:3",4",2" & $C: 5 "$ & C:3",4",2" & $C: 5 "$ & C:3",4",2" \\
\hline
\end{tabular}

Table 4. Results of Antibacterial Activities of Compounds 1-6

\begin{tabular}{|l|l|l|l|}
\hline & \multicolumn{3}{l|}{ Zone of inhibition in $\mathrm{mm}$} \\
\hline Compounds & E. coli & S. aureus & P. vulgaris \\
\hline $\mathbf{1}$ & 11.5 & 13.8 & 12.7 \\
\hline $\mathbf{2}$ & 15.4 & 14.6 & 11.5 \\
\hline $\mathbf{3}$ & 14.5 & 14.8 & 12.8 \\
\hline $\mathbf{4}$ & 10.8 & 12.7 & 10.8 \\
\hline $\mathbf{5}$ & 12.8 & 13.7 & 10.8 \\
\hline $\mathbf{6}$ & 12.7 & 12.9 & 10.9 \\
\hline Positive control & Amikacin & Vancomycin & Penicilin \\
& 16.8 & 15.5 & 13.4 \\
\hline
\end{tabular}




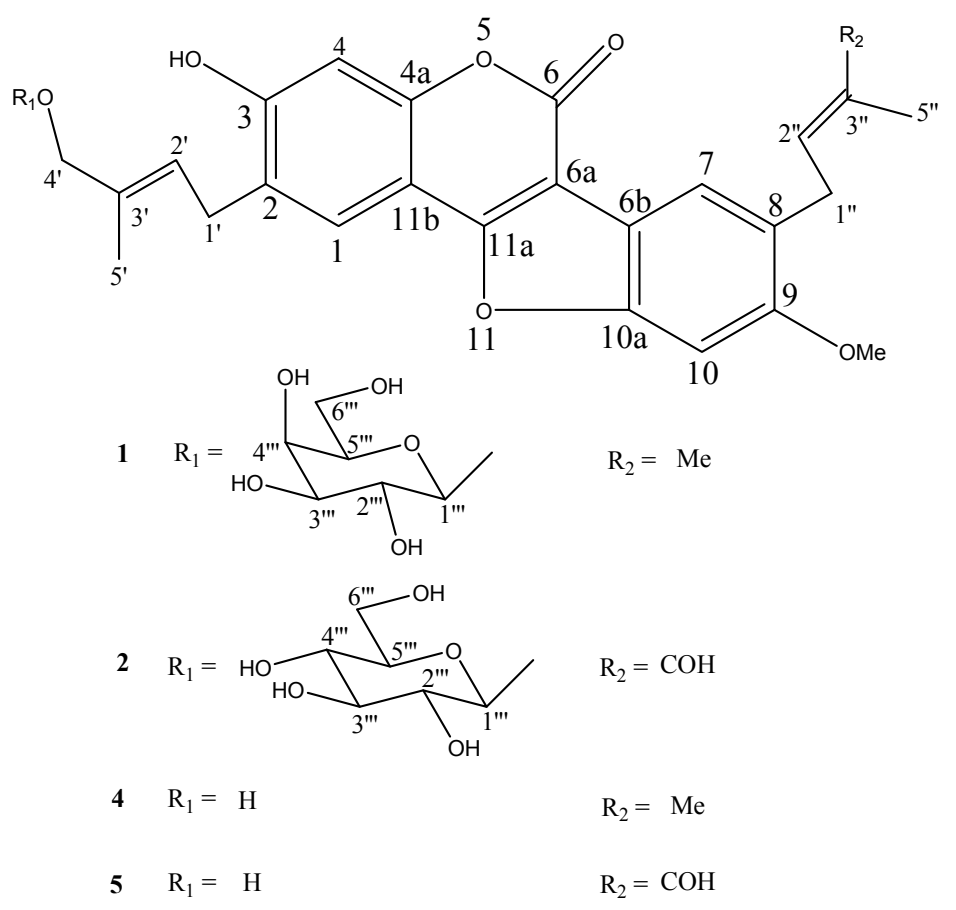

Figure 1. Structures of Compounds 1, 2, 4 and 5

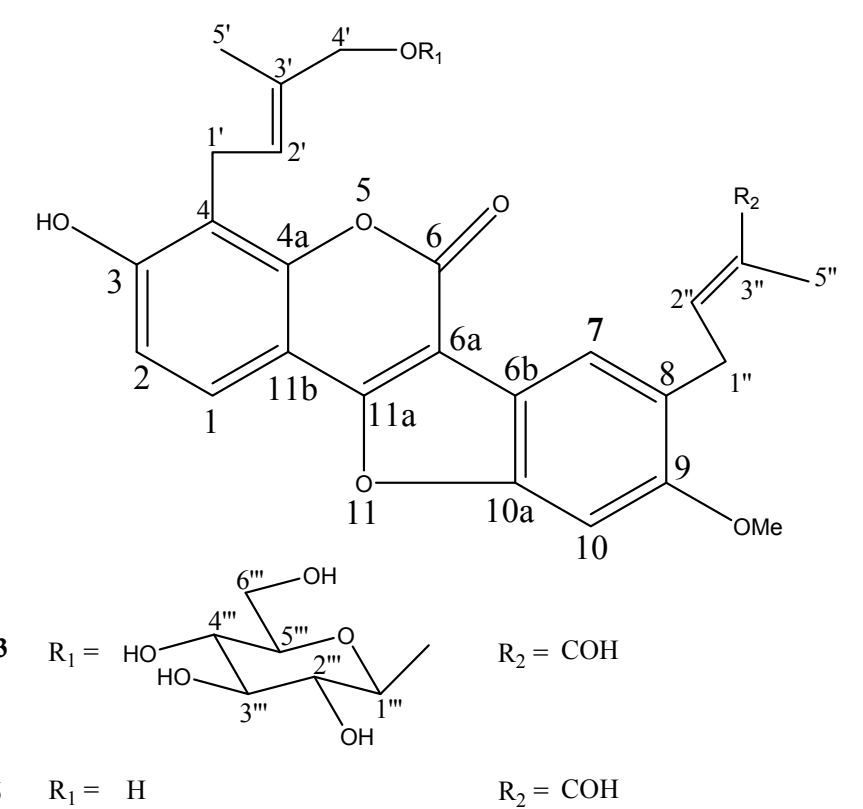

Figure 2. Structures of Compounds $\mathbf{3}$ and $\mathbf{6}$ 